\title{
Hydrothermal Gold Mineralization and Structural Controls near May Hibey, Northwestern Tigray, Northern Ethiopia
}

\author{
Mickiale Giday ${ }^{1}$ and Bheemalingeswara Konka ${ }^{2 *}$ \\ ${ }^{1}$ Department of Earth Science, College of Natural and Computational Science, Arba Minch \\ University, Arba Minch, Ethiopia \\ ${ }^{2}$ Department of Earth Science, College of Natural and Computational Science, P.O. Box 3066, \\ Mekelle University, Mekelle, Ethiopia (*kbheema2006@gmail.com)
}

\begin{abstract}
Ezana Mining Development Company has recently reported presence of gold mineralization near May Hibey area, western Tigray, northern Ethiopia. It is in association with hydrothermal quartz veins within the Neoproterozoic low grade basement rocks, metavolcanics and metasedimentary rocks. Structural data suggests four phases of deformations and NE-SW trending foliation is the prominent one among others. Among different generations of veins, NNE, NS and NNW trending third generation quartz veins are gold-bearing and presence of a narrow shear zone with dextral sense of movement trending NW-SE is significant interms of mineralization. Hydrothermal alterations are dominated by chloritization and sericitization. Core samples from shear zone within the sericite-quartz schist and quartz porphyry rocks shows presence of pyrite, pyrrhotite, sphalerite, chalcopyrite, galena and gold in decreasing order of abundance. Gold mineralization is closely associated with the sericite and carbonization alteration zone. Based on mineral association, alteration, deformation, texture, and paragenetic scheme, it is suggested that the mineralization is a syn-orogenic variety formed in an island arc tectonic setting.
\end{abstract}

Keywords: Quartz veins, Shear zones, Gold, Petrography, Geochemistry, MayHibey, Ethiopia.

\section{INTRODUCTION}

Ethiopia is endowed with various types of metallic and non-metallic mineral resources such as gold, platinum, copper, lead, zinc, tantalite-columbite, manganese, molybdenum and potash (Aspermont, 2011). The mining sector being in the infantile stage in the country, these resources are contributing very little to the country's economic growth (Aspermont, 2011). Increased mineral exploration activities for the last two decades due to the initiatives taken by the government, has resulted in locating many metallic and non-metallic deposits in different parts of the country (Tadesse, 2009; Getaneh and Tadesse, 2015). Among others, major focus of several mining companies and researchers has been the gold and base metal deposits, occurring in low grade basement rocks of Neoproterozoic age. Gold occurrences are reported from southern, western and northern parts of the country but base metals, volcanogenic massive sulfide (VMS) type (some are gold-bearing) are mainly reported in northern Ethiopia (Bheemalingeswara and Atakilty, 2012; Samuel et al., 2015). All the reported gold deposits are in the advanced stage of exploration, not reached exploitation stage except 1) Legadembi gold mine in southern Ethiopia 
which is presently operated by MIDROC company; and 2) recently started Meli auriferous gossan open pit mine in northern Ethiopia by Ezana Mining Development Company (EMD), a Tigray-based local company. Meli gossan, 30m deep, developed on VMS deposit, and estimated to have $\sim 2 t$ gold (Bheemalingeswara and Atakilty, 2012).

Gold mineralizations reported in the country include: i) brittle-ductile shear-zone related "mesothermal" gold deposits in Lega Dembi, Megado and Sakaro area; ii) brittle-ductile shearzone related "mesothermal" gold deposits in Adi Dairo-Indallilo area; iii) $\mathrm{Au}-\mathrm{Cu}-\mathrm{Pb}-\mathrm{Zn}$ in Ashashire; (western Ethiopia) iv) $\mathrm{Au}-\mathrm{Cu}$ in Bomo; v) $\mathrm{Au}-\mathrm{Cu}-\mathrm{Pb}$ in Digati; vi) ductile shear zone-hosted mesothermal gold mineralization in south Okote area; vii) mesothermal type gold in south-west Akebo area, viii) epithermal gold in the rift valley and Afar regions; and ix) Au, Ag Alluvial-eluvial placers in southern, western and northern Ethiopia (Tadesse, 2009; Deksissa, 2004).

In northern Ethiopia, National Mining Company has indicated the presence of structurally controlled gold mineralized zones of gold near Workamba. The mineralization was later studied in detail with reference to petrography, fluid inclusion, isotope geochemistry and age dating by Gebresilassie (2009) and concluded that it is syn-orogenic lode gold mineralization with similarities to Legadembi gold deposit (Tadesse, 2004). Beijing Donia Resources Company and Ezana Mining Development Company (EMD) have reported the presence of volcanogenic massive sulfide (VMS) type $\mathrm{Cu}-\mathrm{Zn}$ - Au- Ag deposits near Terer, Terakimti and Adi Bladie; and eluvial-diluvial gold in western Tigray. Sheba mining company has conducted drilling in Hawzein area and reported presence of hydrothermal gold and base metal mineralization (Zelalem, 2015). EMD has reported gold mineralization at May Hibey (Mickiale, 2014) and VMS deposit at Meli (Samuel et al., 2015) in NW Tigray. Like many VMS deposits, Meli VMS is also a gold-bearing (Barrie et al., 2007; Mercier-Langgevin et al., 2011) and produced auriferous gossan due to weathering and higher gold values due to residual concentration (Bheemalingeswara and Atakilty, 2012). Although, the reports suggest presence of gold and base metal mineralizations in many areas, but detailed studies on different aspects of these deposits are underway. May Hibey is one such gold mineralization in northern Ethiopia, considered for study to understand ore petrography, alterations patterns, structure and paragenesis and the results are presented here. 


\subsection{The study area}

The study area is located in the northwestern Tigray region of northern Ethiopia and $\sim 294 \mathrm{~km}$ northwest of Mekelle city (Fig 1). The area is bounded by $1,545,650 \mathrm{~m}$ to $1,548,750 \mathrm{~m} \mathrm{~N}$ and $387,130 \mathrm{~m}$ to $390,000 \mathrm{~m} \mathrm{E}$ and covers an area of about $9 \mathrm{~km}^{2}$. It is accessible by an asphalt road from Mekelle through Shire to Endabaguna and all weather gravel road from Endabaguna to Meli and the study area, May Hibey. The area is characterized by moderately rugged topography with elevations ranging from $1002-1302 \mathrm{~m}$ amsl and dendritic drainage pattern. May-Tsekente is the main river that flows from northwest to southeast. It is sparsely vegetated with thorny bushes, indicating semi-arid conditions.

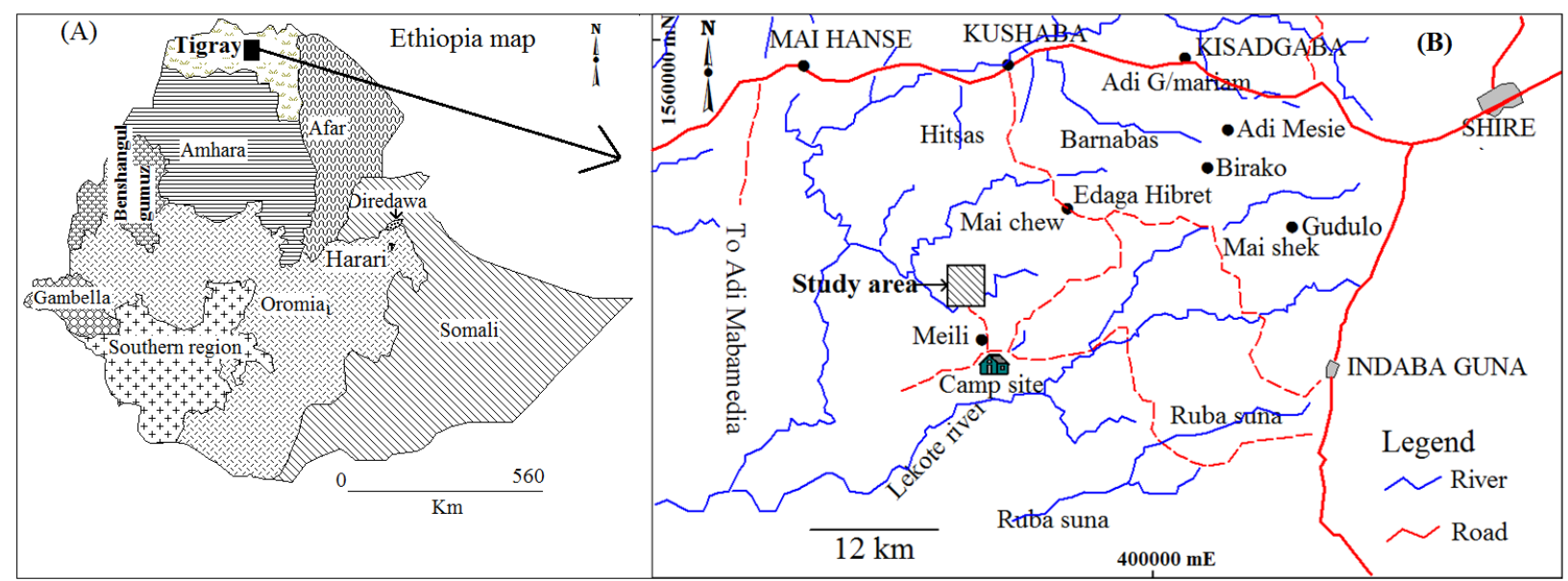

Figure 1. Map showing A) Tigray region, and B) Location of the study area.

\subsection{Previous Work}

Howe $(2009,2011)$ carried out investigations for mineral deposits, and produced a geological map, recorded alterations patters and potential target areas for further mineral exploration. Howe (2009) conducted a reconnaissance study covering relatively larger area i.e. Rahwa Block and in 2011 by integrating geochemical and geophysical results as part of mineral exploration and delineated zones for further exploration for gold and base metals around May Hibey. Keeping this in view, EMD has conducted detailed stream sediment, soil and lithogeochemical survey around May Hibey and reported anomalous concentrations of gold and base metals in association with quartz veins. EMD conducted follow-up trenching and demarcated anomalous ore zones and conducted diamond drilling mainly for gold mineralization in May Hibey area during 201314. 


\section{METHODOLOGY}

Detailed fieldwork was conducted in the area and produced a geological map and collected for both surface and core samples for microscopic study and geochemical analysis. Ezana company has made 35 diamond drills at $55^{\circ}$ dip with different azimuth trends, out of which, seven boreholes were selected for detailed logging and sampling (Fig 2). They include MH-BH-02, MH-BH-05, MH-BH-06, MH-BH-08, MH-BH-14, MH-BH-18 and MH-BH-21. Selected surface and core rock samples were used for petrographic studies $(n=13)$. Thin and polished rock sections were prepared at Ethiopian Geological Survey laboratory, Addis Ababa and studied at the School of Earth Science, Mekelle University using transmitted and reflected light microscopes. Selected samples $(n=10)$ were analysed for major oxide geochemical data using $X$ ray Fluorescence Spectrometer (XRF) on pressed pellets using rock standards as reference in Geological Survey of Ethiopia laboratory, Addis Ababa (Table 1). Gold data used in the paper is from EMD, generated by assay method in Ezana laboratory in Mekelle (Mickiale, 2014).

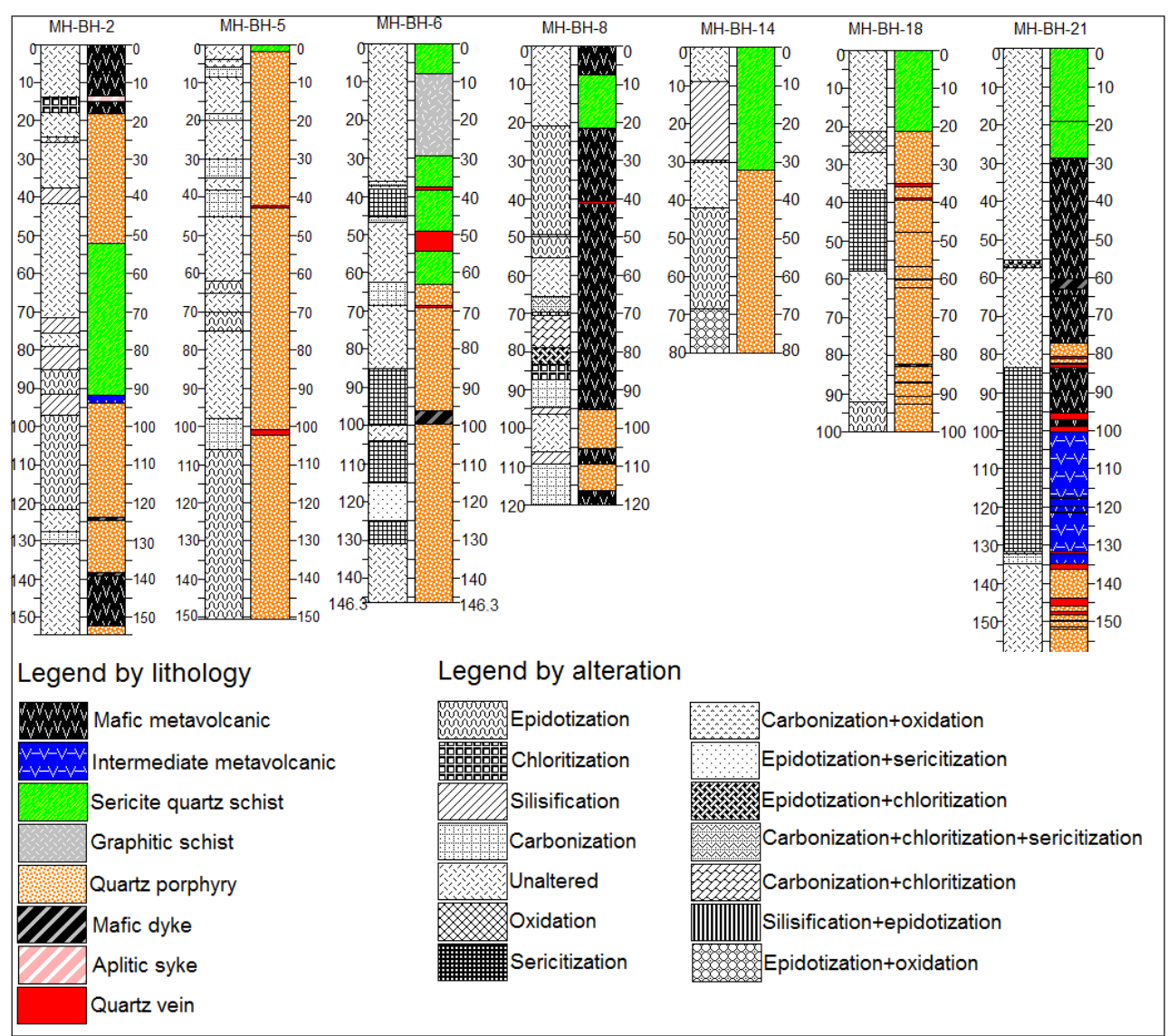

Figure 2. Drill core logs showing the subsurface lithologies and alterations. The numbers on the left and right side of the log indicate depth in meter, the log in the left is for alterations and the right with colors for lithologies. 


\section{GEOLOGICAL SETTING}

\subsection{Regional Geology}

Ethiopian geology starts from Precembrian in general and Neoproterozoic in particular and forms the southern part of Arabian Nubian Shield (ANS). Geology of northern Ethiopia is dominated by low grade rocks belonging to ANS whereas the southern part is also represented by the high grade rocks Mozambic belt in addition to the rocks of ANS (Kazmin, 1971; Asrat et al., 2001). Detailed account of northern part of Ethiopia is provided by Tadesse et al. (1999) in their study on the Axum sheet, northern Ethiopia. This study provides an insight into the geology of northern Ethiopia based on geochemistry of the low grade metavolcanic rocks from the PanAfrican Axum area. Tadesse et al. (1999) have also suggested the presence of accreted intraoceanic arc sequences with varied lithological and geochemical characteristics. Accordingly, six tectonic bounded and north to northeast trending tectonostratigraphic sequences were identified including; the Shiraro, Adi Hageray, Adi Nebrid, Chila, Adwa and Mai Kenetal Blocks. The geology of each block is summarized in detail by Tadesse et al. (1999). The study area is related to Adi Nebrid Block (of Axum sheet) which is located within the Nakfa tectono-stratigraphic sequence of Eritrean basement. According to Tadesse et al. (1999), the Adi Nebrid Block is comprised of thick southeast dipping mafic to intermediate metavolcanics, pyroclastic rocks and immature volcaniclastic sediments. The metavolcaniclastic rocks are intruded by a series of postand pre- tectonic granites, dykes, and mafic/ultramafic intrusive and quartz veins. The general geological history and setting of the region is quite understandable that accretionary tectonics followed by metamorphism, intrusions, deposition and uplifting has become the main events which controlled the structural evolution of the region. Structurally characterized by the presence of a series of anticlines and synclines, wide spread shear zones trending NE-SW with sinistral slip movement and thrusting with NW vergence in contact with Zager mafic/ultramafic intrusives (Tadesse et al., 1999).

\subsection{Geology of the Study Area}

The area forms part of basement of northern Ethiopia and consists of metavolcanics, metavolcaniclasts, metasediments and syn-tectonic granite and younger intrusive, quartz veins of different generations, and aplitic and mafic dykes. Lithounits present in the area are shown in figure 3A. They are affected by tectonics and undergone deformation and attained different orientations. The rocks mainly show NE-SW orientation with NE diping. Mostly, the rocks are 
fine to medium grained and show well developed foliation. Presence of accessory minerals like magnetite and pyrite are also noted in some of the lithounits. The details of lithologies are provided hereunder.

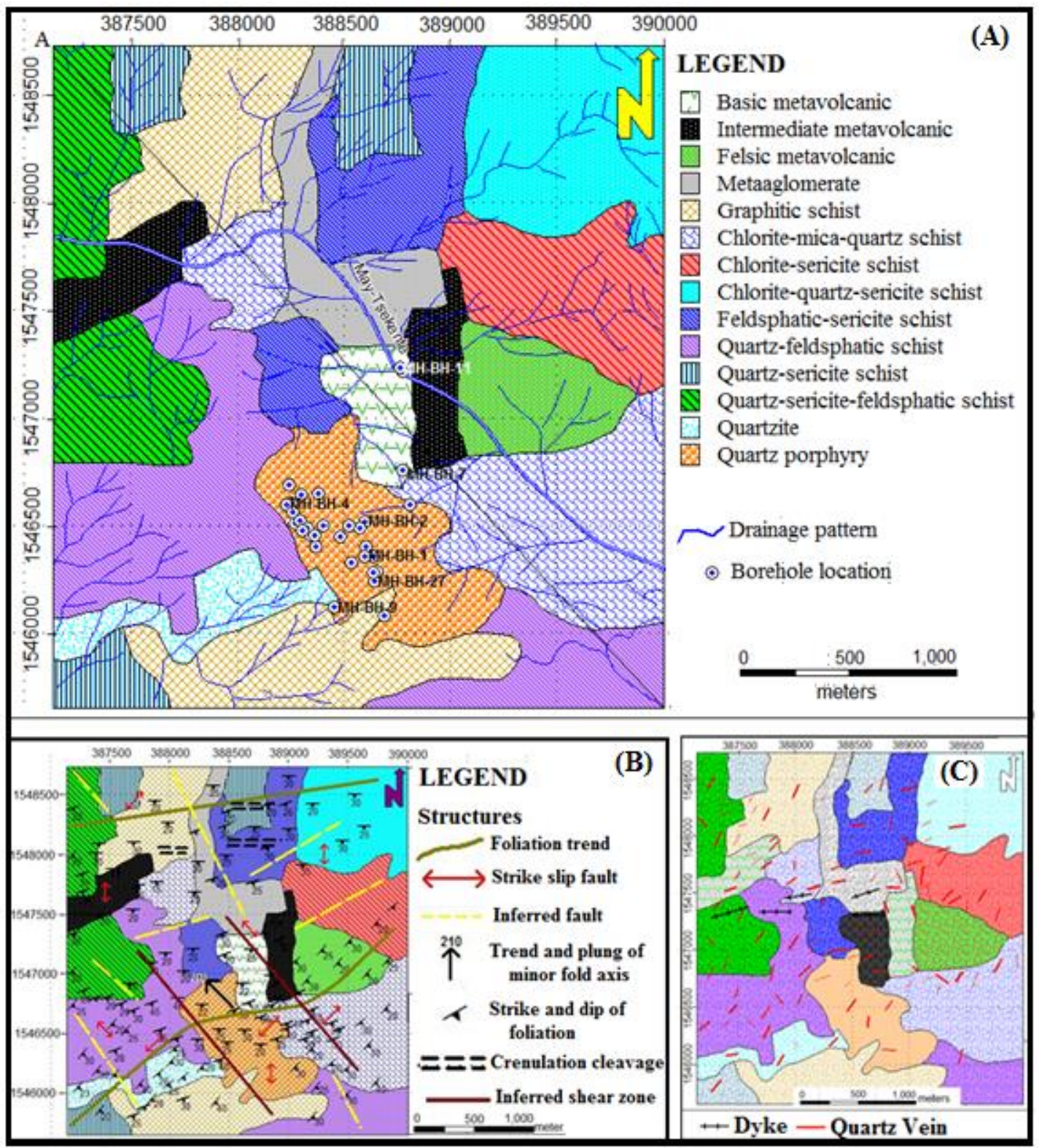

Figure 3. (A) Geological map of May Hibey area with borehole locations; (B) structures; and (C) quartz veins and dykes distribution.

Metavolcanic rocks vary in composition from mafic to intermediate to felsic and exposed mainly in the central, eastern and northern part of the study area. The basic/mafic metavolcanic rock shows gradational contact with quartz porphyry, intermediate metavolcanic, metaaglomerate and 
feldsphatic sericite schist. It is dark green and shows development of E-W foliation and with moderate to sub-vertical dips (Fig 3B). The rock is affected by normal faulting followed by strike slip movements and consists of NE trending fracture filling numerous thin quartz stringers and quartz veins. Petrographic data indicate presence of chlorite, amphiboles, muscovite, biotite and opaques as accessories (Mickiale, 2014). The intermediate metavolcanic rock is mainly composed of muscovite, chlorite, quartz and few plagioclase feldspar minerals. It is medium to dark green, fine to medium grained and moderately foliated. It shows porphyritic texture where the coarse grains show epidotization. The rock present in the western part of the study area shows N-S trend with a dipping towards east with dip amount of $\sim 30^{\circ}$, while the rock cropped out in the central part shows E-W trend dipping $65^{\circ}$ towards south (Fig 3B). The felsic metavolcanic rock exposed in the eastern part is fine grained with white, grey, brown colors. Petrographic study indicate presence of quartz and feldspars as dominant minerals with sericitization and kaolinization alterations. Foliation shows N-S orientation and the rock is intruded by quartz veins of different orientations and thickness varying from 1 to $20 \mathrm{~cm}$. Metaagglomerate/metavolcaniclast rock present in the central part and extends northward consists of clasts showing angular, rounded to sub-rounded and elongated shapes and ranging in size from 0.5 to $40 \mathrm{~cm}$ in their longer axis and 0.3 to $5.5 \mathrm{~cm}$ in the short axis. The longer axis indicates elongation (stretching) due to deformation.

Metasedimentary rocks on the other hand vary in composition and are represented by graphitic schist, chlorite-mica-quartz schist, chlorite quartz sericite schist, quartz sericite schist with gradational contact. Naming of these metasedimentary rocks is done based on the petrographic data. Graphite schist shows well-developed schistocity and at places it is very massive, jointed and shows black color. It is trending NW-SE direction similar with the adjacent quartz -sericite schist andhosts minimum amount of quartz veins. Interestingly, most of the veins running through quartz -sericite schist are seen terminating at the contact with graphite schist.

Chlorite -mica- quartz schist shows green color due to chlorite with fairly well developed schistocity trending NW-SE. Development of chloritization and epidotization and presence of few quartz veins is common in this unit. Towards northeastern part of the area the amount of quartz decreases and sericitization increases and changes to chlorite -sericite schist (Fig 3). The rock shows green color due to chlorite which is coarser compared to sericite which is generally fine to medium in size. Another unit, feldsphatic sericite schist is also trending similar to quartz 
sericite schist, mostly present in the ridge slopes composed mostly of feldspar, sericite and quartz with indications of kaolinization. The unit is intercalated with chlorite schist and mica schist. The rock is highly jointed and hosts many quartz veins and veinlets. Quartz-feldsphatic schist trending NW-SE is present in the western and south eastern part of the study area. The unit in the south eastern part is less affected compared to the western part which is bit massive highly jointed and hosts many quartz veins. It is composed mostly of feldspar and quartz minerals. Quartz-sericite schist is exposed mainly in the northern and northwestern part of the area and is fine grained white to pink in color, massive, welded and jointed. It is composed mainly of quartz and sericite and found hosting many quartz veins and veinlets. Local miners are also found working on the quartz veins present in quartz-sericite schist.

Quartz-sericite-feldsphatic schist rock is similar to quartz-sericite schist except with minor amount of feldspars. It shows similar NW-SE trend and hosts many quartz veins varying in size from few $\mathrm{mm}$ to $5 \mathrm{~m}$. Quartzite unit is composed of tight interlocking grains of quartz and minor amount of coarse grained feldspar minerals. The rock shows NE-SWorientation and is nonfoliated (Fig 3). Quartz porphyry unit is composed mainly of quartz with fine groundmass. It consists of rounded to sub-rounded clasts of blue quartz eyes and varies in size from few $\mathrm{mm}$ to $3 \mathrm{~cm}$. The quartz clasts are rotated, deformed, stretched and elongated along the foliation plane and showed developed tails as shear sense indicators like beta and delta structures with mostly showing dextral shear sense.

\subsection{Geological Structures}

Fractures, folds and faults and accordingly developed foliations, schistocity, shear zones, veins and dykes are the common geological structures observed in the area. The structural data suggest that the rocks in the area have experienced at least four phasesdeformation. Different types of structures present in the area are shown in figure 3B and orientation of foliations, joints, veins and dykes are shown in figure 4 . The first phase of deformation event $\left(\mathbf{D}_{1}\right)$ has produced the penetrative foliation $\left(S_{1}\right)$ which is prominent in the metasedimentary rocks. The $S_{1}$ foliation is the major structural element in the area following the regional trend NE-SW. and dips $20^{\circ}$ to $45^{0}$ due southeast. In addition, NE-SW trending parasitic folds and development of lineation are also observed in northeastern part of the study area which are parallel to the foliation trends. The second event of deformation $\left(\mathbf{D}_{2}\right)$ is characterized by the development of minor antiformal folds observed in the quartz- feldspar- sericite schist located in the south central part of the area. These 
folds have a general hinge line trending $N 60^{\circ} \mathrm{W}$ and plunging by $\sim 50^{\circ}$ in which the $\mathrm{S}_{1}$ foliations are folded around these minor $\mathrm{F}_{2}$ folds. Disharmonic crenulation cleavage and thrusting are also part of this phase of deformation. $\mathrm{S}_{2}$ is represented by $\mathrm{E}-\mathrm{W}$ trending fractures. These fractutes cut $\mathrm{S}_{1}$ fabric as well as E-W trending sheared and less deformed barren quartz veins.

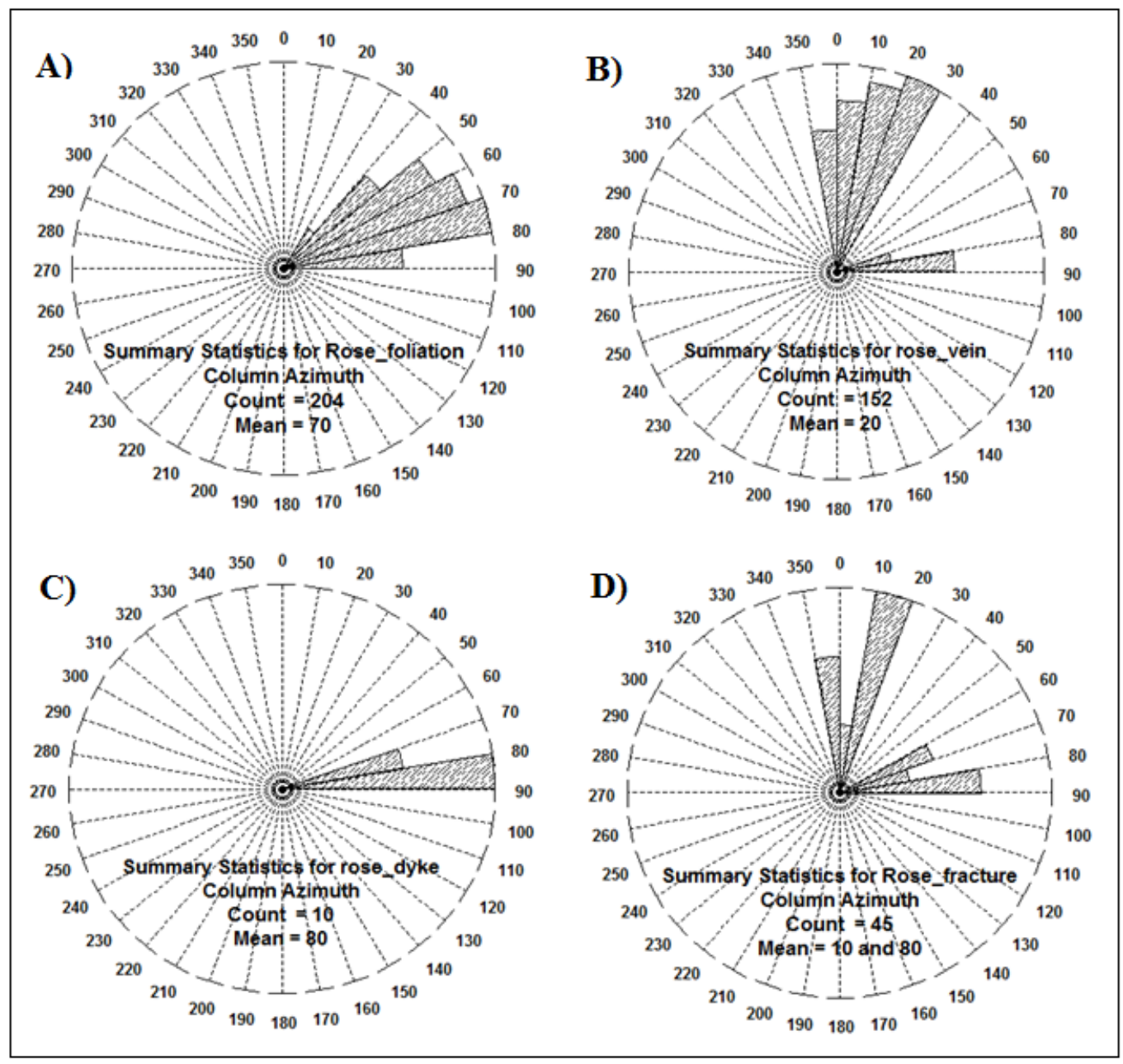

Figure 4. Rose diagram showing orientations of A) foliations, B) quartz veins, C) dykes, and D) fractures, May Hibey area.

The third phase of deformation ( $\left.\mathbf{D}_{3}\right)$ is represented by NW-SE striking and vertically dipping brittle-ductile shear zones within the quartz porphyry transact, the generally NE-SW structural grains of the area. The rocks in the shear zones are strongly silicified. Sulphidization and mineralized quartz veining are common features in these shear zones. Rotated $\sigma$ structures and horizontally E-W plunging mineral aggregate and elongation lineation in the shear zone, invariably indicate a dextral strike slip sense of movement during the $\mathrm{D}_{3}$ deformation in the area. 
The last deformation event ( $\left.\mathbf{D}_{4}\right)$ has produced NW-SE and NE-SW faults with sinisitral sense of displacement and joints of variable orientations. These late structures cut all the preceding structural elements.

\subsection{Hydrothermal Veins- Types and Orientations}

Veins are epigenetic and the prodcuts of hydrothermal systems. Two types of veins, quartz and calcite veins are present in the area though, quartz veins are dominant (Fig 3C). Calcite veins and veinlets are white in color, reacts with dil $\mathrm{HCl}$, few $\mathrm{mm}$ to $\sim 2 \mathrm{~cm}$ in thickness, and mostly observed in the boreholes MH-BH-06, MH-BH-18 and MH-BH-21. Quartz veins are widespread and vary in width from $<1 \mathrm{~cm}$ (small stringers) to $>1 \mathrm{~m}$. Two types of veins are observed in the area, non-deformed veins (extensional veins) and deformed veins (shear veins/compression shear veins). The extensional variety are dominant, upto $5 \mathrm{~m}$ wide and $30 \mathrm{~m}$ long with milky white color whereas the deformed veins are rare, thin, with variegated colors and sheared and deformed and restricted to northern and eastern and central parts of the area.

Based on the field observation, petrographic study and their cross cutting relationships; four generations of quartz veins are noted in the area. The first generation represent thin $(\sim 1-5 \mathrm{~cm}$ thick), folded and deformed veins, trending $\mathrm{NE} 40^{\circ}$ and filling the foliation mainly in quartzsericite schist and sericite-chlorite schist rocks. These are related to the D1 deformation. The second, third and fourth generations of the veins are not highly deformed. The second and third generation quartz veins are identified based on their cross cutting relation whereas the fourth generation is represented by calcite veinlets cutting the earlier generation quartz veins. It is observed in both the field and petrographic study (MH-BH-21-13) (Mickiale, 214). Most of the second generation quartz veins are wider and mostly barren, boudinaged, sheared, fractured, faulted, and consists of milky quartz. These veins are mostly filling the E-W fractures and foliations and related to D2, while, the third generation quartz veins exhibit varying colors, white, grey, smoky, yellowish, brown and reddish and cut across the E-W trending veins and belong to D3 (mostly mineralized). Field observations based on the cross-cutting relations, the veins trending ENE $\left(075^{\circ}\right)$ and E-W are relatively older compared to veins striking at NNE $\left(025^{\circ}\right)$ and NNW $\left(350^{\circ}\right)$ directions (Figs 3C and 4).

It is interesting to note that the veins trending $000^{0}-050^{0}$ vary in thickness between $0-5 \mathrm{~m}$ where as the veins trending $300^{\circ}-360^{\circ}$ vary between $10-20 \mathrm{~m}$. Mostly these veins are barren. Other veins trending NS, NNW and NNE are generally $<1 \mathrm{~m}$ thick. These are mineralized and related to D3. 


\section{RESULTS AND DISCUSSION}

\subsection{Ore Petrography}

The study of polished sections indicates presence of native gold and sulfides (Fig 5 A-F). Sulfides include pyrite, pyrrhotite, chalcopyrite, galena and sphalerite. The polished sections composed of fine to medium grained, and euhedral (with cubic outlines) to subhedral yellow pyrite, brown irregular pyrrhotite, grey sphalerite, medium to fine irregular cream galena, medium to fine grained brass yellow chalcopyrite and fine grained gold showing isotropic property with golden yellow color. They are mainly associated with quartz veins and are disseminated. Gangue minerals often occur within the pyrite showing poikilioblastic texture.
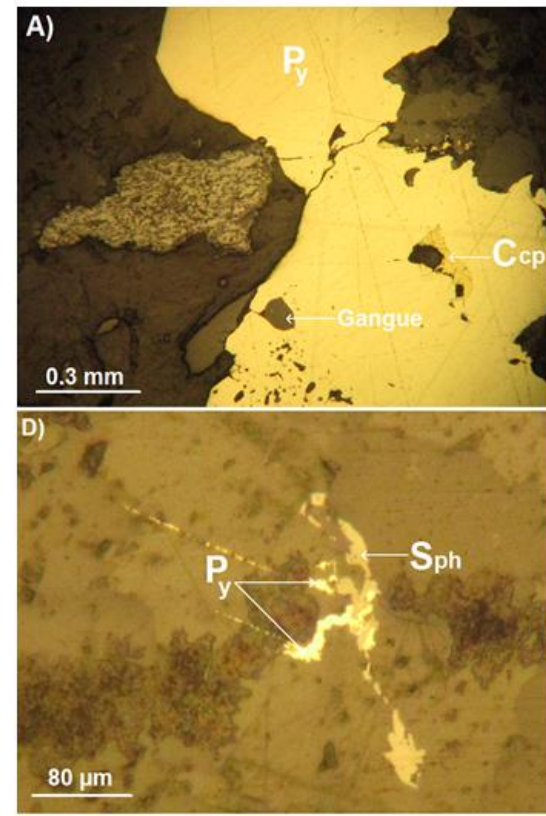
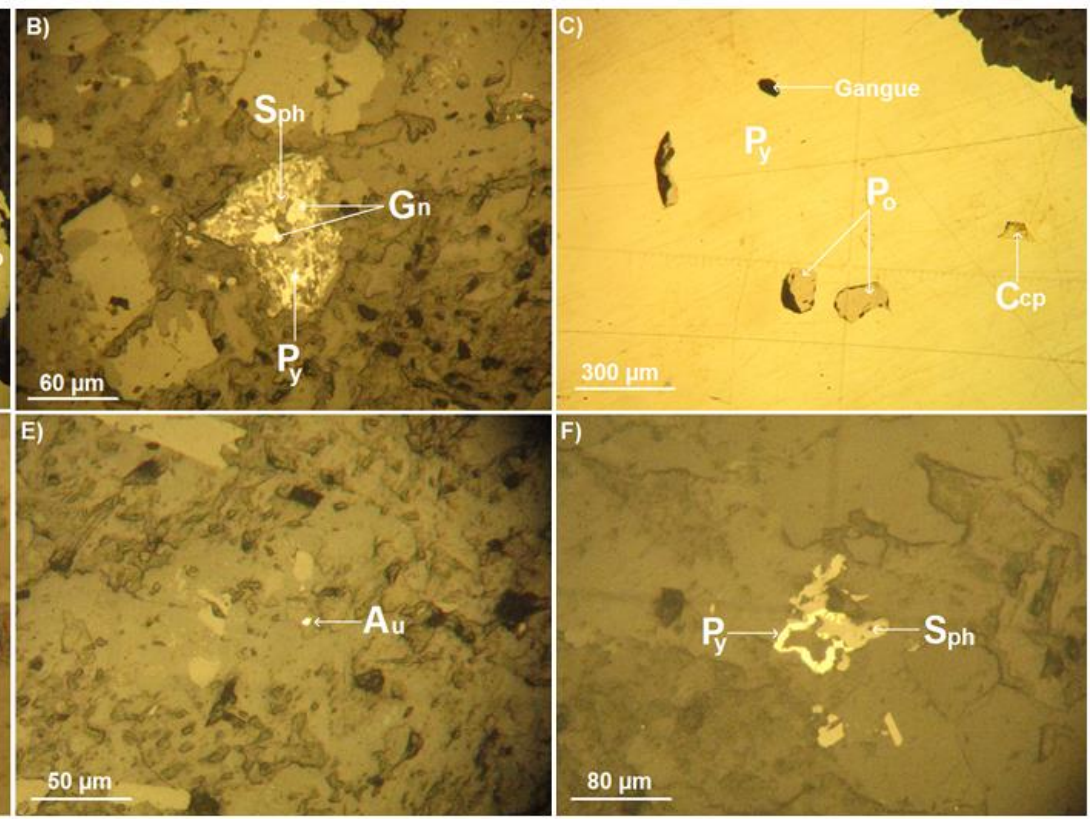

Figure 5. Reflected-light photomicrographs under PPL, A) chalcopyrite and gangue inclusions within pyrite; B) sphalerite replaced by galena and with fine grained pyrite inclusion;C) pyrrhotite, chalcopyrite and gangue inclusions within pyrite; D) sphalerite replaced by pyrite; E) gold grain inquartz vein; and F) sphalerite replacement by pyrite and pyrite forming rim around the gangue. $\mathrm{P}_{\mathrm{y}}=$ pyrite, $\mathrm{P}_{\mathrm{o}}=$ pyrrhotite, $\mathrm{C}_{\mathrm{cp}}=$ chalcopyrite, $\mathrm{S}_{\mathrm{ph}}=$ sphalerite, $\mathrm{G}_{\mathrm{n}}=$ galena and $\mathrm{Au}=$ gold .

Two types of pyrites are observed in the section based on form, fracturing, fracture filling attitude. Based on the mineral assemblage and their relationships, the sulfides are related to two generations, pyrite and pyrrhotite represent first phase whereas chalcopyrite, sphalerite, galena and gold the second phase. Pyrite related to first phase shows development of fractures, 
alteration and is cut by the younger veins and minerals. The pyrite of second phase on the other hand is free from alteration and with minimum fracturing. The fractures in pyrite are filled by gangue and other sulfides like sphalerite. The second phase pyrite seems to be associated with gold which is fresh. They also show later re-mobilization.

\subsection{Host Rock Geochemistry}

Major oxide geochemical data of metavolcanic and intrusive rocks indicate positive correlation for $\mathrm{SiO}_{2}$ with $\mathrm{Na}_{2} \mathrm{O}$ and $\mathrm{K}_{2} \mathrm{O}$ and negative correlation with $\mathrm{Al}_{2} \mathrm{O}_{3}, \mathrm{CaO}, \mathrm{MgO}$ and $\mathrm{Fe}_{2} \mathrm{O}_{3}$ (Mickiale, 2014). Positive correlation of major oxides with $\mathrm{SiO}_{2}$ clearly indicates normal igneous trends and display systematic variation in chemical composition from basic to acidic. The major oxides and their trends are similar and comparable with the metavolcanic rocks of Adi Nebrid block (Tadesse et al., 1999).

Table 1. Whole rock geochemical data of the rocks of the study area (from Mickiale, 2014).

\begin{tabular}{|c|c|c|c|c|c|c|c|c|c|c|}
\hline Rock type & \multicolumn{3}{|c|}{ Metavolcanic rock } & \multicolumn{3}{|c|}{ Metasedimentary rock } & \multicolumn{4}{|c|}{ Intrusive } \\
\hline 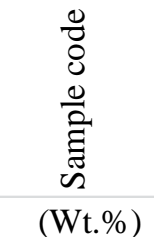 & 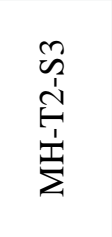 & 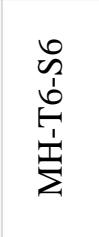 & 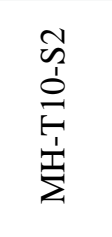 & 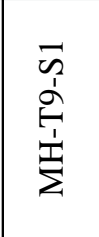 & $\begin{array}{l}\overrightarrow{0} \\
1 \\
01 \\
1 \\
1 \\
1 \\
1 \\
\Sigma\end{array}$ & 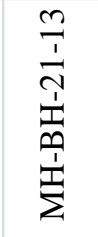 & 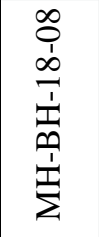 & $\begin{array}{l}n \\
0 \\
1 \\
0 \\
1 \\
1 \\
0 \\
1 \\
1 \\
\Sigma\end{array}$ & 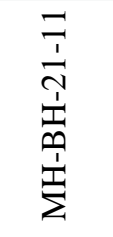 & 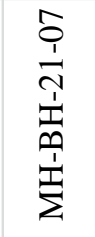 \\
\hline $\mathrm{SiO} 2$ & 48.64 & 71.98 & 47.64 & 69.7 & 97.1 & 57.18 & 56.2 & 65.74 & 64.66 & 50.52 \\
\hline $\mathrm{Al} 2 \mathrm{O} 3$ & 17.64 & 15.06 & 17.34 & 12.75 & 1.16 & 14.14 & 15.75 & 15.99 & 15.73 & 15.33 \\
\hline $\mathrm{Fe} 2 \mathrm{O} 3$ & 15.06 & 0.88 & 15.28 & 4.38 & 0.52 & 7.74 & 10.24 & 2.68 & 3.84 & 11.2 \\
\hline $\mathrm{CaO}$ & 10.14 & 0.16 & 4.94 & 0.2 & 0.76 & 6.2 & 7.66 & 1.9 & 3.4 & 4.74 \\
\hline $\mathrm{MgO}$ & 4.6 & 0.16 & 7.8 & 4.88 & 0.52 & 3.04 & 3.1 & 1.38 & 2.4 & 3.04 \\
\hline $\mathrm{Na} 2 \mathrm{O}$ & 2.8 & 4.68 & 2.44 & 0.6 & 0.52 & 4.06 & 2 & 2.94 & 4.12 & 3.46 \\
\hline $\mathrm{K} 2 \mathrm{O}$ & 0 & 2.3 & 0.34 & 1.98 & 0.02 & 0.18 & 0.9 & 1.86 & 2.5 & 1.16 \\
\hline $\mathrm{MnO}$ & 0.52 & 0.16 & 1.02 & 0.12 & 0.06 & 0.2 & 0.32 & 0.08 & 0.1 & 0.2 \\
\hline $\mathrm{P} 2 \mathrm{O} 5$ & 0.25 & 0.04 & 0.03 & 0.1 & 0.03 & 0.04 & 0.2 & 0.02 & 0.19 & 0.59 \\
\hline $\mathrm{TiO} 2$ & 0.73 & 0.08 & 0.41 & 0.36 & 0.04 & 0.37 & 0.62 & 0.24 & 0.65 & 1.99 \\
\hline $\mathrm{H} 2 \mathrm{O}$ & 0.17 & 0.22 & 0.35 & 0.11 & 0.15 & 0.21 & 0.58 & 0.44 & 0.21 & 0.28 \\
\hline LOI & 3.38 & 1.23 & 5.56 & 3.58 & 0.64 & 6.46 & 2.09 & 2.94 & 3.06 & 4.09 \\
\hline Sum & 103.93 & 96.95 & 103.15 & 98.76 & 101.52 & 99.82 & 99.66 & 96.21 & 100.86 & 96.6 \\
\hline
\end{tabular}

Petrographic analysis of metavolcanic rock samples (sample MH-T2-S3) shows schistosity with coarse mafic and plagioclase minerals in fine grained ground mass matrix and suggests that the protolith is possibly porphyry basalt (Mickiale, 2014). XRF data of the same sample shows 47 wt.\% $\mathrm{SiO}_{2}$ and when plotted falls in basalt field. Another sample MH-T10-S2 also suggests basalt protolith with $47.64 \mathrm{wt} \% \mathrm{SiO}_{2}$. Similarly, petrography of felsic metavolcanic rock (sample 
MH-T6-S6) that suggests rhyolite as protolith is comparable with geochemical data (71.98 wt.\% $\mathrm{SiO}_{2}$, Table 1). Simiarly, the intrusive rocks - mafic (MH-BH-21-07), intermediate (MH-BH-1808) and acidic (MH-BH-18-05; MH-BH-21-11) are also comparable with geochemical data $50.52 \mathrm{wt} \% ; 56.2 \mathrm{wt} \%$; and $65.74 \mathrm{wt} \%$; and $64.66 \mathrm{wt} \% \mathrm{SiO}_{2}$ respectively (Mickiale, 2014).

Petrography of metasedimentary rocks shows considerable variation in the rock type and alteration type. The protolith broadly varies from sandstone to shale with variation in composition. Sandstone is related to metasandstone/quartzite and shale to muscovite -quartz schist, quartz schist, sericite-quartz schist, graphitic schist. In these rocks silica content is ranging between 57.18 and $97.10 \mathrm{wt} \%$. $\mathrm{Al}_{2} \mathrm{O}_{3}$ values are high as expected except in quartzite sample (MH-BH-18-01) which shows $1.16 \mathrm{wt} \% \mathrm{Al}_{2} \mathrm{O}_{3}$ and $97.10 \mathrm{wt} \% \mathrm{SiO}_{2}$ and low values for $\mathrm{CaO}$, $\mathrm{K}_{2} \mathrm{O}$ and $\mathrm{Na}_{2} \mathrm{O}$.

The discriminating diagram for tectonic setting indicates that the rocks are formed in an island arc setting (Fig 6) and is similar to the reports by different workers for other areas in northen Ethiopia (Alene et al., 2000; Bheemalingeswara and Nata, 2009; Samuel et al., 2015; Stern, 1994).

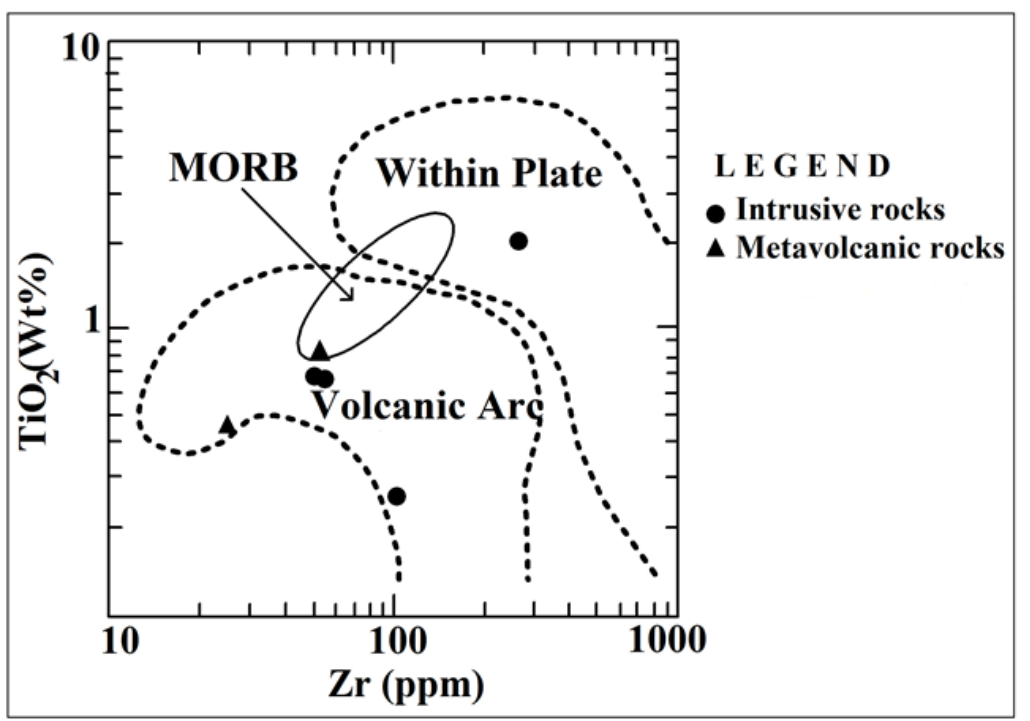

Figure 6. Tectonic setting discrimination diagram (Pearce, 1980)(Zr data from Samuel, 2012).

\subsection{Gold Mineralization and Structural Control}

Gold occurs in disseminated form, in association with quartz veins and vary in concentration. In borehole $\mathrm{MH}-\mathrm{BH}-02$ the maximum values recorded is 1.6ppm; in $\mathrm{MH}-\mathrm{BH}-05$ upto 26ppm; $\mathrm{MH}-$ BH-06 upto 139.69ppm; MH-BH-08 <1ppm; MH-BH-18 2ppm; and MH-BH-21 20ppm. 
Quartz veins and associated gold mineralization with reference to depth, gold concentration, alteration and host rock association for two boreholes is shown in figure 7 . It is compared with the trench data and shown in figure 8. Gold-bearing quartz veins occur at different depths and varies from 40 to $80 \mathrm{~m}$ in length. Gold values observed in borehole samples and trench samples are quite variable. Gold values in two boreholes (Fig 7) occurring at a depth of about 40 to $60 \mathrm{~m}$ when compared to the trenche data (the trenches are in the same orientation) (Fig 8), the gold values vary significantly, where trench values are high, borehole value is not high and vice versa. Such relation is related to selective enrichment and dessiminated behavior of gold, and pinch and swell behavior of quartz veins.

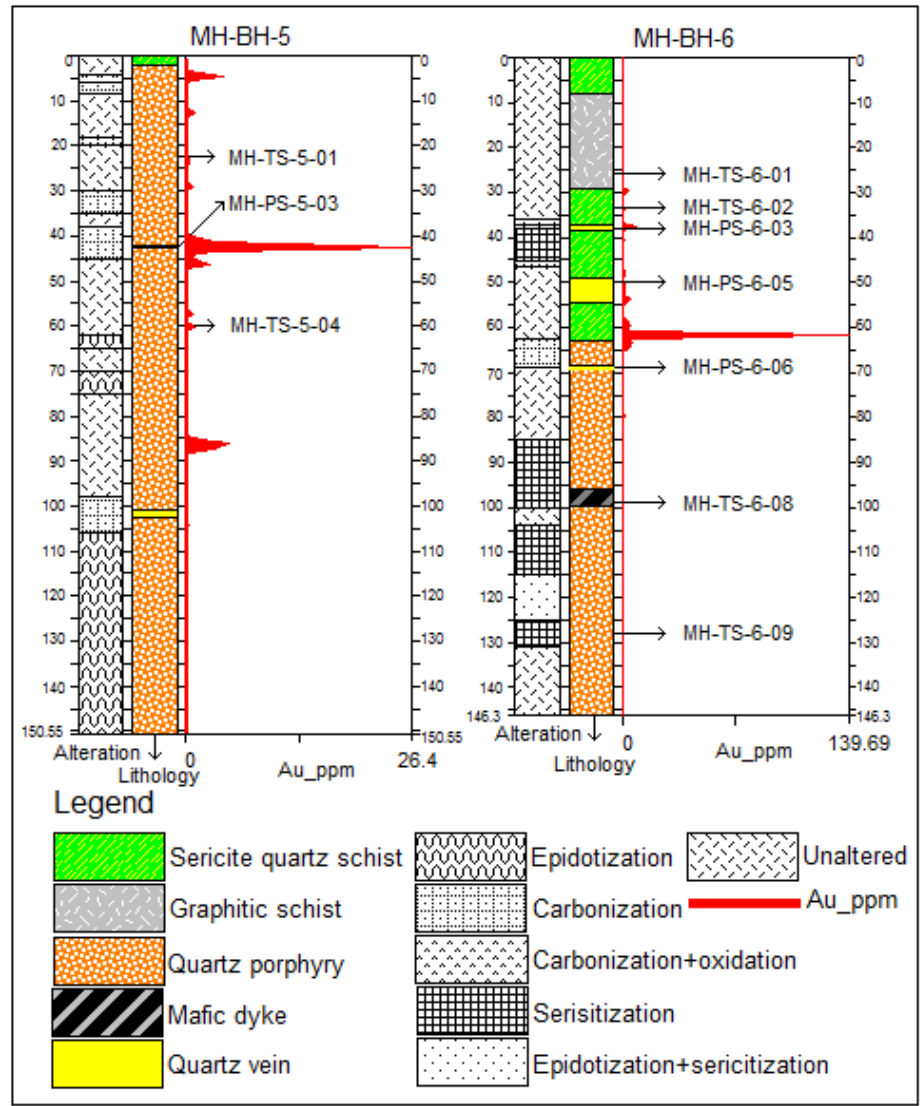

Figure 7. Gold concentration values in boreholes $\mathrm{MH}-\mathrm{BH} 5$ and 6, its relation to host rocks and alterations (Gold data from EMD).

The base metal sulfides present quartz veins are insiginicant in terms of their abundance. This is typical of lode gold deposits related to syn-orogenic conditions e.g. Legadembi (Tadesse, 2004) and Workamba (Gebreselassie, 2009). Though, gold and base metal sulfides are observed in quartz veins in the core samples, gold association with base metal sulfides and pyrite is not very 
clear in polished sections. The gold grains observed in the polished sections are found in isolation not associated with sulfides (Fig 5). This may be due to close association of gold with sericite alteration and carbonization (Fig 7) which indicates possible re-mobilization of gold and its isolation with sulfides (Fig 5).

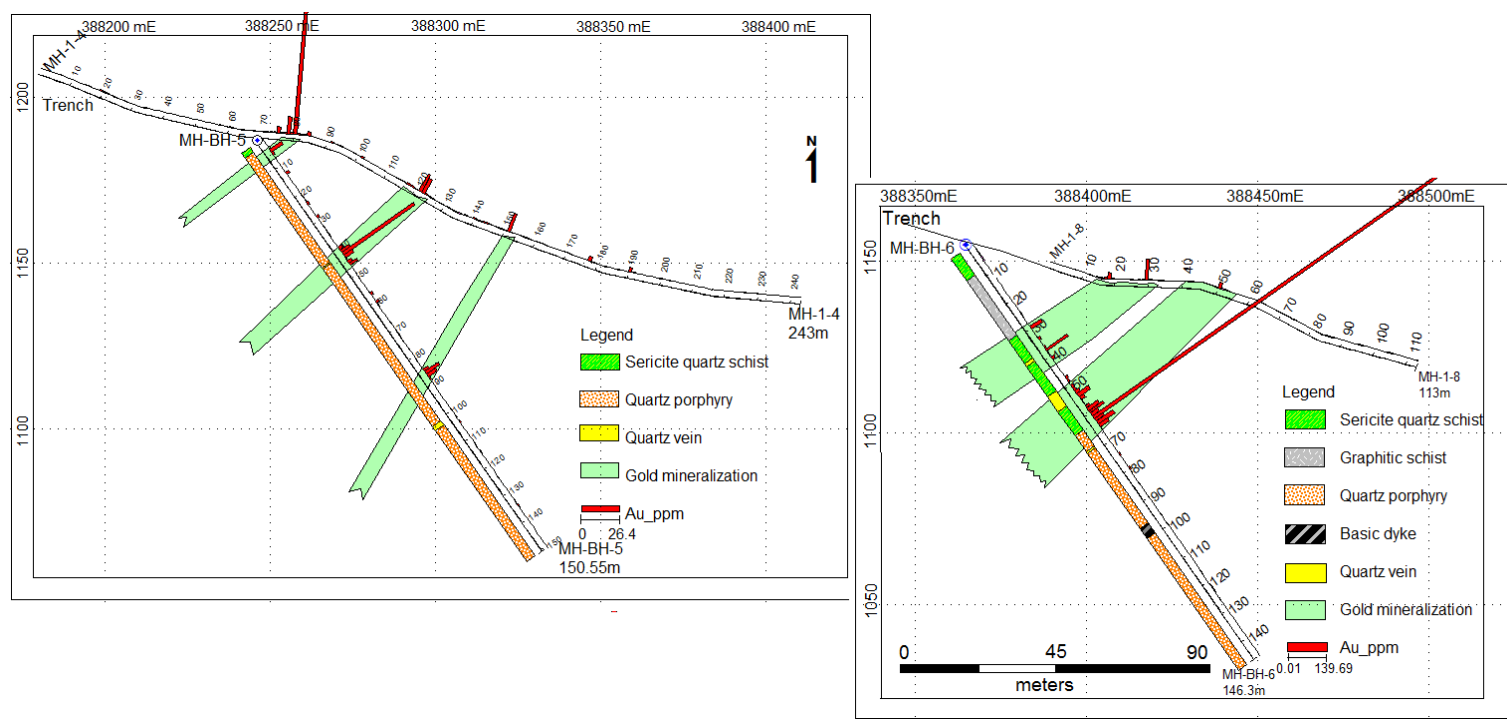

Figure 8. Gold concentration values in trench and borehole (MH-BH 5 and MH-BH6) samples, its relation to host rocks and alterations, May Hibey (Data from EMD). (Note: Scale is same for both figures).

Among the geological structures, fractures and shear zones are playing a major role in vein development and ore concentration. Fractures act as pathways for the hydrothermal solutions to form fracture filling quartz veins. The shear zones due to having closely spaced fractures facilitates increased solution activity, fluid and country rock interaction, and development of different alteration zones e.g. propylitic, sericitization, silicification, carbonatization etc. It also facilitates development of alteration halos, replacement textures and destruction of metamorphic fabrics. Mineralization in the area is seen confined to the central part of the area whereas alteration is common in different parts of the area though extensive in the NW trending shear zone which is developed due to local faulting and shearing (Fig 3). Similarly, quartz veins though are well distributed in the area, the veins associated with shear zone show high content of gold (Fig 3 and 7). Gold mineralization is thus strongly related structure in the area.

\subsection{Paragenetic Sequence}

In terms of paragenetic sequence of sulfides and gold, pyrite is followed by other sulfides and gold. Pyrite dominates other sulfides and occur as porphyroblast in the rock and hydrothermal 
variety in the quartz veins. The first variety is formed during diagenetic process or due to break down of primary mafic minerals during metamorphism. The second variety is formed as part of hydrothermal process. In both the cases, it shows disseminated nature but mostly euhedral in the former and irregular in the later. Among the hydrothermal variety, pyrite further shows two types, one with development of fractures and alteration, where as the younger ones are mostly fresh, mostly irregular, relatively small in size and free from fractures and alteration. The fractured pyrite is later filled by gangue and other sulfides. Apart from pyrite, magnetite is also found present within the country rock particularly the mafic rocks, formed during alteration. Sericite, biotite, chlorite, iron hydroxides and epidote are other minerals formed during the alteration process.

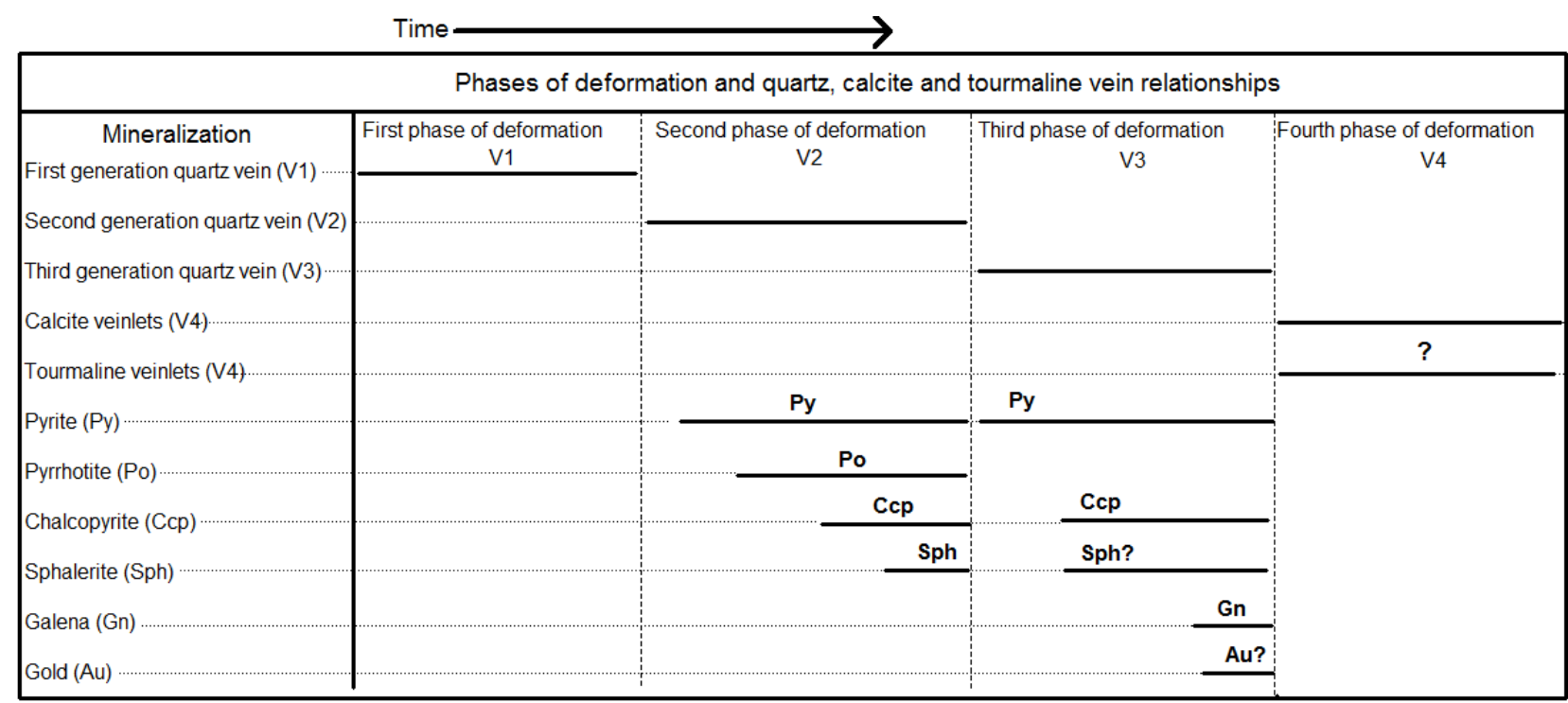

Figure 9. Paragenetic scheme showing relative temporal relationship between phases of deformation, generation of the veins and sulfide minerals.

Among the two generations of pyrite, the older one is found in association with pyrrhotite, and the younger one with chalcopyrite, sphalerite, galena and gold. Among the sulfides, pyrite I is followed by pyrrhotite, pyrite II, chalcopyrite and sphalerite. Pyrrhotite is present as inclusion in pyrite I. Chalcopyrite replaces pyrrhotite showing replacement texture. Sphalerite, pyrite II, galena, chalcopyrite and gold are related to third phase quartz veins related to D3 deformation. The paragenetic sequence with reference to deformation is presented in figure 9.

\subsection{Genesis of Gold Mineralization}

Gold mineralization at May Hibey is formed as part of a hydrothermal process and confined to locally developed shear zone. Since, gold mineralization is associated with the third generation 
quartz veins, it is related to later coming solutions as part of metamorphic and tectonic conditions. Keeping in view the association of gold mineralization to fractures, shear zone, sericirization and carbonization alteration and low grade metamorphic conditions, the ore forming fluids are possibly related to metamorphic process operating in the temperature ranges of about $300^{\circ} \mathrm{C}$ (Ridley, 2013) rather than the intruisive plutons which can also contribute to such hydrothermal process. According to Klein et al. (2005); Goldfarb et al. (2001); Groves et al. (1998), orogenic lode gold deposits are typically formed during late stages of the deformationalmetamorphic-magmatic history of the evolving orogens, syn-kinematics with at least one main penetrative deformation stage of the host rocks. This conclusion is based on many observations made for gold deposits that were structurally cut across fabrics formed during orogenesis, and most of the deposits are largely unaffected by early orogenic deformation. In the case of May Hibey, gold mineralization is confined to low-medium grade greenschist facies metamorphic conditions and hosted mainly in sericite quartz schist and quartz porphyry rocks. Gold occurs in fracture filling veins and veinlets mainly within the third generation veins striking NNE, N-S and NNW and confined to shear zone. The mineralization is characterized by a relatively low abundance of sulfides (pyrite, pyrrhotite, sphalerite, chalcopyrite and galena), presence of pyrrhotite with chalcopyriute (which indicates ultramafic/mafic source, deeper), and selective enrichment and association of gold with sericite and carbonization alteration. Boudinaged and attenuated quartz shear vein, fractured quartz vein, faulted quartz vein within the shear zone suggests the auriferous quartz veins are formed syn and/or post shearing and prior to $\mathrm{D}_{4}$ phase deformation. Therefore, the structural setting, host rock alteration, and sulfide mineralogy suggest an orogenic-gold type mineralization at May Hibey. Based on the results, May Hibey mineralization may be related to the shear zone-hosted gold mineralization in Workamba, northern part of Ethiopia (Gebresilassie, 2009) and orogenic shear-zone hosted hydrothermal lode gold deposit in Lega Dembi, southern Ethiopia (Tadesse, 2004).

\section{CONCLUSION}

May Hibey area forms a part of Neoproterozoic stratigraphy of northern Ethiopia and comprises of metavolcanics, metavolcaniclastics, metasediments and intrusive syn-tectonic granites. These rocks are intruded by the younger aplitic, mafic dykes and quartz veins. Mineral assemblage, foliation and schistose texture suggest that the rocks of the study area have experienced low- 
medium grade greenschist facies metamorphism and shows development of different types of alterations related to metamorphism and hydrothermal activity. The alterations include propylitic, argillic, phyllic, oxidation, silicification and carbonatization. Structural analysis of the May-Hibey area indicates that the area has undergone four phases of deformation (D1 to D4). The geochemical data indicate that the metavolcanic rocks are derived from calk alkaline to tholeiite magma generated in island arc environment. The gold mineralization occurs together with sulfides in quartz veins and associated with carbonization and serisitizatioon wall rock alteration zones. Mineralization is hosted by intensely sheared and hydrothermally altered greenschistfacies assemblages of metavlocanic and metasedimentary rocks. Mineralization is structurally controlled and occur within the third generation quartz veins which are oriented towards NNE $\left(025^{\circ}\right)$, NS and NNW $\left(340^{\circ}\right)$ directions. The gold mineralization is interpreted as syn-orogenic lode gold type and comparable with other gold deposits elsewhere in the country.

\section{ACKNOWLEDGMENTS}

Financial support provided by Arbaminch and Mekelle Universities are duly acknowledged. The suppost provided by Ezana mining company is highly appreciated for providing support in the field for stay and fieldwork, supplying core samples and allowing to use unpublished geochemical data. Mekelle University is also thanked for providing vehicle for field work.

\section{REFERENCE}

Alene, M., Ruffini, R \& Sacchi, R. 2000. Geochemistry and geotectonic setting of Neoproterozoic rocks from northern Ethiopia (Arabian-Nubian Shield). Gondwana Research,3: 333-347.

Aspermont, UK. 2011. Ethiopia facts and proud independence. Albert house, 1 singer street London EC2A 4BQ. Mining journal special publication, Ethiopia, 15p.

Asrat, A., Barbey, P \& Gleizes, G. 2001. The Precambrian Geology of Ethiopia: A review. Africa Geoscience Review, 8: 271-288.

Barrie, C. T., Nielson, F. W \& Claude, H. 2007. The Bisha, volcanic-associated massive sulfide deposit, Western Nakfa terrane, Eritrea. Society of Economic Geologists, Inc. Economic Geology, 120:717-738. 
Bheemalingeswara, K \& Nata Tadesse. 2009. Petrographic and geochemical study of low grade metamorphites around Negash with a reference to base metal mineralization and ground water quality, Tigray, northern Ethiopia. Momona Ethiopian Journal of Science, 1(2): 106-132.

Bheemalingeswara, K., Solomon Gebresilassie \& Kassa Amare. 2012. Shear zone-hosted base metal mineralization near Abraha Weatsbeha-Adi Desta and Hawzen, Tigray Region, Northern Ethiopia. Momona Ethiopian Journal of Science, 4(1): 3-28.

Bheemalingeswara, K \& Atakilty Araya, 2012. Rahwa auriferous gossan, northern Ethiopia: A strong indicator of subsurface massive sulfide mineralization. International Journal of Earth Sciences and Engineering, 5(3): 402-408.

Deksissa, D. J. 2004. Geochemistry, alteration, and genesis of gold mineralization in the Okote area, southern Ethiopia. Geochemical journal, 38: 07-331.

Gebresilassie, S. 2009. Nature and characteristics of metasedimentary rock hosted gold and base metal mineralization in the Workamba area, central Tigray, northern Ethiopia. Ph.D. thesis, at Ludwig-Maximilians University, Munich, Germany, 134 p.

Getaneh, W \& Tadesse, S. 2015. Text book of economic geology. Addis Ababa University Press, ISBN: 978-99944-52-58-3, Addis Ababa, 306p.

Goldfarb, R. J., Groves, D. I \&Gardoll, S. 2001. Orogenic gold and geologic time: a global synthesis. Ore Geology Reviews, 18: 1-75.

Groves, D. I., Goldfarb, R. J., Gebre-Mariam, M., Hagemann, S. G \&Robert, F. 1998. Orogenic gold deposits: A proposed classification in the context of their crustal distribution and relationship to other gold deposit types. Ore Geology Reviews, 13: 7-27.

Howe International LTD, 2009. Filed visit report on the May Hibey exploration license Tigray province, Northern Ethiopia. Berkhamsted Herts, UK. (Unpubl.).

Howe International LTD, 2011. Satellite image interpretation of the May Hibey block, Tigray Ethiopia. Berkhamsted Herts, UK. (Unpubl.).

Kazmin, V. 1971. Precambrian of Ethiopia. Nature, 230:176-177.

Klein, E. L., Harris, K., Giret, A., Moura, C. A. V \& Angelica, S. R. 2005. Geology and stable isotope $(\mathrm{O}, \mathrm{H}, \mathrm{C}, \mathrm{S})$ constraints on the genesis of the Cachoeria gold deposit, Gurupi Belt, northern Brazil. Chemical Geology,221: 188-206. 
Mercier-Langgevin, P., Hannington, M.D., Dube, B \& Becu, V. 2011. The gold content of volcanogenic massive sufide deposits. Mineralium Deposita,46:509-539.

Mickiale, G. 2014. Geological, petrographical and geochemical study of gold mineralization in May-Hibey, northwestern Tigray, Ethiopia. M.Sc thesis, Department of Earth Science, Mekelle University, Ethiopia. 110p (unpubl.).

Pearce, J.A. 1980. Geochemical evidence for the genesis and erupting setting of lavas from Tethyan ophiolites In: A. Panayiotou (ed), Ophiolites. Proceedings of International symposium. Geological Survey Department, Nicosia, Cyprus, pp 261-277.

Ridley, J. 2013. Ore deposit geology. Cambridge University Press, ISBN: 978-1-107-02222-5, $398 \mathrm{p}$.

Samuel, A. 2012. Geology and characteristics of the volcanogenic massive sulfide mineralization at Meli, northwestern Tigray, Ethiopia. MSc thesis, Department of Earth Science, Mekelle University, Ethiopia, 91p (unpubl.).

Samuel, A., Bheemalingeswara, K \& Solomon, G. 2015. Geology of volcanogenic massive sulfide deposit near Meli, northwestern Tigray, northern Ethiopia. Momona Ethiopian Journal of Science, 7(1): 85-104.

Stern, R. J. 1994. Arc assembly and continental collusion in the Neoproterozoic East African orogen: Implications for the consolidation of Gondwanaland. Annual Review of Earth Science, 22: 319-351.

Tadesse, S. 2004. Genesis of the shear zone related gold vein mineralization of the Lega Dembi gold deposit, Adola gold field, Southern Ethiopia. Gondwana Research,7(2): 481-488.

Tadesse, S. 2009. Mineral resources potential of Ethiopia. Addis Ababa University Press, ISBN: 978-99944-52-14-9, Addis Ababa, 290p.

Tadesse, T., Hoshino, M \& Sawada, Y. 1999. Geochemistry of low-grade metavolcanic rocks from the Pan-African of the Axum area-Northern Ethiopia. Precambrean Research,99: $101-124$.

Zelalem, H. K. 2015. Geological, petrographic and geochemical investigation for gold and base metal mineralization in Shelewa area, Tigray State, northern Ethiopia. MSc thesis, Department of Earth Science, College of Natural and Computational Sciences, Mekelle University, Mekelle, Ethiopia, 94p (unpubl.). 